\title{
AKIBAT HUKUM KEPAILITAN PERSEROAN TERBATAS
}

Erlina

\author{
Universitas Islam Negeri (UIN) Makassar
}

Email : erlina_fshuin@yahoo.co.id

\begin{abstract}
Limited liability company declared bankrupt does not necessarily stop and disperse but still exist as legal entity. In certain circumstances still exist running its business as usual limited liability company does not happen bankruptcy and still able to do business activity. This is due to the company declared bankrupt have an economic value (economic value) is much higher than the value of the company's assets. Because the bankruptcy is actually destined for companies that have negative assets. Nevertheless, the decision to continue the bankruptcy company resulted in the power of the board of directors in a limited liability company. However, with the bankruptcy statement, the debtor by law lost the right to control and manage his property which was inserted into the bankruptcy property as of the date of the decision of bankruptcy.
\end{abstract}

\section{Keywords: Limited Liability Company, Bankruptcy, Receiver}

\begin{abstract}
Abstrak
Perseroan terbatas yang dinyatakan pailit tidak serta merta berhenti dan bubar melainkan masih eksis sebagai badan hukum. Dalam keadaan tertentu masih eksis menjalankan usahanya seperti lazimnya perseroan terbatas tidak terjadi kepailitan dan tetap dapat melakukan kegiatan usahanya. Hal ini diakibatkan perseroan dinyatakan pailit mempunyai nilai ekonomis (economic value) yang jauh lebih tinggi dibanding nilai aset perusahaan tesebut. Oleh karena kepailitan sebenarnya diperuntukkan terhadap perusahaan yang mempunyai aset negatif. Namun demikian, keputusan untuk melanjutkan perseroan pailit mengakibatkan kekuasaan direksi dalam suatu perseroan terbatas.. Namun dengan adanya pernyataan pailit, debitor demi hukum kehilangan hak untuk menguasai dan mengurus harta kekayaannya yang dimasukkan ke dalam harta pailit terhitung sejak hari putusan pernyataan pailit tersebut.
\end{abstract}

Kata kunci : Perseroan Terbatas, Kepailitan, Kurator 


\section{PENDAHULUAN}

utusan pailit oleh pengadilan tidak mengakibatkan debitor kehilangan
kecakapannya untuk melakukan perbuatan hukum (volkomen
handelingsbevoegh) pada umumnya, tetapi hanya kehilangan kekuasaan atau kewenangannya untuk mengurus dan mengalihkan harta kekayaannya saja. Dengan demikian, debitor tetap dapat melakukan perbuatan hukum, misalnya menikah, membuat perjanjian kawin, menerima hibah, bertindak menjadi kuasa, dan mewakili pihak lain. Namun, kepailitan mengakibatkan debitor yang dinyatakan pailit kehilangan segala "hak perdata" untuk menguasai dan mengurus harta kekayaan yang telah dimasukkan kedalam budel harta pailit. ${ }^{1}$ Pembekuan hak perdata ini diberlakukan oleh Pasal 21 Undang-Undang Nomor 37 Tahun 2004 Tentang Kepailitann dan Penundaan Kewajiban Pembayaran Utang (untuk selanjutnya disebut UU Kepailitan) terhitung sejak saat keputusan pernyataan pailit diucapkan.

Kepailitan tidak mengakibatkan debitor kehilangan kemampuannya untuk melakukan perbuatan hukum yang menyangkut dirinya, kecuali apabila perbuatan itu menyangkut pengurusan dan pengalihan harta bendanya yang telah ada. Apabila menyangkut harta benda yang akan diperolehnya, debitor tetap dapat melakukan perbuatan hukum menerima harta benda tersebut, namun tetap menjadi bagian dari harta pailit.

Putusan pernyataan pailit mengakibatkan mengubah status hukum seseorang atau suatu badan hukum menjadi tidak cakap melakukan perbuatan hukum. Sejak putusan penyataan pailit diucapkan tindakan pengurusan dan pengalihan harta benda debitor menjadi wewenang dari kurator. Gugatan-gugatan hukum yang menyangkut hak dan kewajiban berkenaan dengan harta kekayaan debitor pailit tersebut harus diajukan terhadap atau oleh kurator. Dengan kata lain, gugatan menyangkut harta kekayaan debitor tidak lagi diajukan kepada debitor tetapi harus diajukan kepada kurator. Demikian pula sebaliknya gugatan terhadap pihak lain tidak lagi diajukan oleh debitor tetapi oleh kurator.

Kasus PT. Nikko Securuties vs PT. Gema Widia Statindo Komputer. Dalam kasus tersebut meskipun gugatan debitur pailit (Gema Widia) ditolak, status debitur yang berada dalam keadaan pailit tidak dijadikan pertimbangan hukum. Seharusnya, sejak diajukan bukti bahwa debitur telah pailit, otomatis gugatan tersebut ditolak. Kecuali gugatan tersebut diajukan oleh kurator.

1 Ahmad Yani dan Gunawan wijaya, Kepailitan (PT RajaGrafindo Persada, Jakarta, 1999), h. 30 
Demikian halnya dalan kasus antara PT. Exim Leasing dan PT. Itamaraya Gold Industry. $^{2}$

Secara hukum, sejak dinyatakannya pailit seketika itu juga debitur tidak memiliki kewenangan untuk melakukan perbuatan hukum. Bahkan pengadilan setempat mengabulkan sita jaminan yang dimintakan oleh debitor pailit terhadap harta kekayaan kreditur yang mengajukan pailit. Permasalahannya adalah bagaimana status harta perusahaan akibat adanya putusan kepailitan? Apakah kepailitan membebaskan debitor yang dinyatakan pailit dari kewajibannya untuk membayar utang-utangnya?

\section{PEMBAHASAN}

Perseroan terbatas dalam bahasa Belanda disebut dengan Naamlooze Vennootschap $(N V)$ dan dalam bahasa Inggris disebut dengan Limited (Ltd) Company atau Limited Liability Company, ataupun Limited (Ltd) Corporation ${ }^{3}$. Perseroan Terbatas terdiri dari dua kata, perseroan dan terbatas. Perseroan merujuk pada modal yang terbagi atas sero-sero atau saham-saham, sedangkan terbatas merujuk pada tanggung jawab pemegang saham yang luasnya hanya terbatas pada nilai nominal semua saham yang dimilikinya ${ }^{4}$.

Perseroan terbatas merupakan artificial legal person badan hukum buatan. Artinya dimata hukum, perusahaan adalah person yang mempunyai hak dan kewajiban seperti layaknya manusia (human person), yaitu sesuai dengan doktrin yang diletakkan house of Lords dalam putusan Salomon v Salomon \& Co. Ltd. Bahwa suatu perseroan adalah person yang terpisah dari pemiliknya ${ }^{5}$.

Badan hukum menurut sifatnya, ada dua macam, yaitu ialah (1) korporasi (corporatie) dan (2) Yayasan (stiching). Korporasi ialah suatu gabungan orang yang dalam pergaulan hukum bertindak bersama-sama sebagai satu subjek hukum tersendiri-suatu personifikasi. Korporasi adalah badan hukum yang beranggota, tetapi mempunyai hak-kewajiban sendiri yang terpisah dari hak kewajiban anggota masing-masing.

${ }^{2}$ Leo Faraytody, 2003, Jangan Tunggu Langit Runtuh. Hukumonline.com.:3

${ }^{3}$ Munir Fuady, Perseroan Terbatas, Paradigma Baru (PT Citra Aditya Bakti : Bandung, 2003), h. 1

${ }^{4}$ Ridwan Khairandy, Perseroan Terbatas, Doktrin, Peraturan Perundang-undangan dan Yurisprudensi (Kreasi Total Media : Yogyakarta), 2009, h. 1

${ }^{5}$ Athur Lewis, alih bahasa Derta Sri Widowatie, Introductioan to Bisnis Law (Dasardasar Hukum Bisnis) (Nusa Media : Bandung, 2009), h. 46 

adalah $^{6}$ :

Pengertian Korporasi (corporation) dalam Black's Law Dictionary

An entity (usu a business) having authority under law to act a single person distrinct from the shareholders who own and having rights to issue stock and axist indefinitely; a group of succesion of persons estabilished in accordance with legal rules into a legal or juristic person that has legal personality distinct from the natural persons who make it up, exists indefinitely apart from them, and has the legal powers that its constitution gives it.

Berdasarkan defenisi tersebut diatas dapat dilihat unsur-unsur yang terdapat dalam korporasi terdapat pula didalam perseroan terbatas. sehingga korporasi adalah badan hukum Semua kewajiban korporasi dijamin dengan harta kekayaannya sendiri, terlepas dari harta kekayaan pemegang sahamnya dan para pengurusnya. Perseroan Terbatas adalah badan hukum yang merupakan persekutuan modal, didirikan berdasarkan perjanjian, melakukan kegiatan usaha dengan modal yang seluruhnya terbagi dalam saham dan memenuhi persyaratan yang ditetapkan undang-undang dan peraturan pelaksanaannya ${ }^{7}$.

Sebagai badan hukum, perseroan harus memenuhi unsur-unsur badan hukum seperti yang ditentukan dalam Undang-undang Perseroan Terbatas. Unsurunsur tersebut adalah organisasi yang teratur, harta kekayaan sendiri, melakukan hubungan hukum sendiri, dan mempunyai tujuan sendiri ${ }^{8}$. Selain itu dalam undang-undang secara tegas telah ditentukan bahwa perseroan terbatas adalah badan hukum ${ }^{9}$.

Atribut badan hukum hanyalah ada apabila undang-undang telah menentukan demikian. Untuk ini ada 2 (dua) teknik yang dilakukan oleh undangundang. Teknik yang pertama, secara tegas undang-undang menyatakan bahwa suatu badan adalah suatu badan hukum. Teknik yang kedua dengan melihat karakteristik yang diberikan oleh suatu ketentuan undang-undang atas suatu badan $^{10}$.

UUPT sudah jelas menentukan perseroan terbatas sebagai suatu badan hukum. Namun, keberadaan status badan hukum sebagai subyek hukum mandiri

${ }^{6}$ Bryan A Garner, Black's Law Dictionary, $8^{\text {th }}$ edition, St Paul, West, 2004, hlm. 365

${ }^{7}$ Lihat Pasal 1 ayat (1) UU No. 40 Tahun 2007 Tentang Perseroan Terbatas

8 Ahmad Yani \& Gunawan Widjaja, Perseroan Terbatas (PT RadjaGrafindo Persada, Jakarta, 2003), h. 8-9

${ }^{9}$ Lihat Pasal I ayat (1) UU No. 40 Tahun 2007 Tentang Perseroan Terbatas

10 Rudhi Prasetya, Kedudukan Mandiri Perseroan Terbatas (Citra Aditya Bakti : Bandung, 2001), h. 28 
juga harus didasarkan pada persyaratan formil. Pada perseroan terbatas, status badan hukum tersebut ditentukan pada saat perseroan memperoleh pengesahan dari Menteri Hukum dan HAM ${ }^{11}$. Hal tersebut memberikan implikasi sifat badan hukum (legal personality), pertama yaitu hak mendahului dari kreditor badan hukum atas harta kekayaan badan hukum pada saat pembubaran badan hukum dilakukan, kedua menunjukkan bahwa harta kekayaan badan hukum tersebut tidak dapat diambil dengan begitu saja oleh para pendirinya atau pemegang sahamnya.

Badan hukum (rechtspersoon) ialah suatu badan yang dapat mempunyai harta, hak serta kewajiban seperti orang pribadi. ${ }^{12}$ Perseroan terbatas sebagai badan hukum memiliki beberapa ciri substansif yang melekat pada dirinya: terbatasnya tanggungjawab pemegang saham, pemilik saham dapat mengalihkan sahamnya kepada pihak ketiga, memiliki kekayaan sendiri, memiliki kewenangan kontraktual $^{13}$. Menurut Subekti ${ }^{14}$ badan hukum adalah suatu perkumpulanperkumpulan mempunyai kekayaan sendiri, ikut serta dalam lalu lintas hukum dengan perantaraan pengurusnya, dapat digugat dan dapat juga menggugat dimuka hakim. Relevan dengan pendapat Chaidir Ali yang menyatakan badan hukum memiliki beberapa ciri substantif yang melekat pada dirinya, yakni terbatasnya tanggungjawab, perpetual succession, memiliki kekayaan sendiri, dan memiliki kewenangan kontraktual serta dapat menuntut dan dituntut atas namanya sendiri. ${ }^{15}$ Karakteristik badan hukum adalah didirikan oleh orang, mempunyai kekayaan sendiri yang terpisah dari kekayaan pendiri atau pengurusnya, mempunyai hak dan kewajiban terlepas dari hak dan kewajiban pendiri atau pengurusnya. ${ }^{16}$

Badan hukum sebagai subyek hukum mandiri yang dipersamakan dengan individu pribadi (pribadi hukum) adalah suatu badan yang memiliki harta kekayaan terlepas dari anggota-anggotanya, dianggap sebagai subyek hukum yang mempunyai kemampuan untuk melakukan perbuatan hukum, mempunyai

${ }^{11}$ Ahmad Yani \& Gunawan Widjaja, Op.Cit, 2003, hlm. 13

12 Rochmat Soemitro, Penuntun Perseroan Terbatas dengan Undang-undang Pajak Perseroan (PT Eresco Bandung : Jakarta, 1979), h. 36

${ }^{13}$ David Kelly, et.al., Business Law, Cavendish Publishing Limited, London, 2002, hlm. 343-345

${ }^{14}$ Subekti, Pokok-pokok Hukum Perdata (Intermasa : Jakarta, 1989), h. 21

${ }^{15}$ Chaidir Ali, Badan Hukum (Alumni : Bandung, 1987), h. 19

16 Peter Mahmud Marzuki, Pengantar Ilmu Hukum (Kencana Prenada Media Group : Jakarta, 2008), h.243 
tanggung jawab dan memilik hak dan kewajiban seperti hak dan kewajiban yang dimiliki seseorang ${ }^{17}$.

Sebagai badan hukum, perseroan terbatas bersifat independen, dengan hak dan kewajiban yang mandiri Oleh karena itu, segala keuntungan yang diperoleh dipandang semata-mata sebagai perbuatan badan itu sendiri. Demikian pula sebaliknya, jika terjadi suatu utang atau kerugian dianggap menjadi beban perseroan terbatas sendiri yang dibayarkan dari harta kekayaan perseroan terbatas ${ }^{18}$.

Perseroan terbatas sebagai badan hukum perdata $^{19}$ tujuan utamanya mengadakan hubungan bisnis dengan pihak lain adalah mencari keuntungan atau laba. ${ }^{20}$ Pada hakikatnya suatu perseroan Terbatas memiliki dua sisi, yaitu pertama sebagai suatu badan hukum dan kedua sebagai wadah tempat diwujudkannya kerjasama antara para pemegang saham atau pemilik modal. Hal ini terlihat jelas dalam ketentuan Pasal 1 ayat (1) Undang-Undang No. 40 Tahun 2007 Tentang Perseroan Terbatas, ditentukan bahwa:

Perseroan Terbatas adalah badan hukum yang didirikan berdasarkan perjanjian, melakukan kegiatan usaha dengan modal dasar yang seluruhnya terbagi dalam saham, dan memenuhi persyaratan yang ditetapkan dalam saham, dan memenuhi persyaratan yang ditetapkan dalam undang-undang ini serta peraturan pelaksanaannya.

Jelas bahwa Perseroan Terbatas merupakan suatu "artificial person", suatu badan hukum yang dengan sengaja diciptakan. Dengan demikian, PT adalah suatu subyek hukum yang mandiri, yang mempunyai hak dan kewajiban, yang pada dasarnya tidak berbeda dengan hak dan kewajiban manusia.

Sebagai subyek hukum yang mandiri, maka keberadaan perseroan terbatas tidak bergantung dari keberadaan para pemegang saham, para anggota direksi, dan dewan komisaris. Pergantian organ perusahaan tidak mempengaruhi keberadaan perseroan terbatas selaku "persona standi in judicio". ${ }^{21}$

${ }^{17}$ Purnadi Purbacaraka dan Agus Brotosusilo, Sendi-sendi Hukum Perdata (CV Rajawali : Jakarta, 1983), h. 51

${ }^{18}$ Rudhi Prasetya, Opcit, h. 9

${ }^{19}$ Chaidir Ali, OpCit, h. 57-64

${ }^{20}$ Abdulkadir Muhammad, Hukum Perusahaan Indonesia (PT. Citra Aditya Bakti : Bandung, 2006), h. 105

${ }^{21}$ Chatamarrasjid, Menyingkap Tabir Perseroan (Piercing The Corporateveil) Kapita Selekta Hukum Perusahaan (PT Citra Aditya Bakti : Bandung, 2000), h.25 
Perseroan Terbatas adalah suatu bentuk perseroan yang didirikan untuk menjalankan suatu perusahaan dengan modal perseroan tertentu yang terbagi atas saham-saham, dalam mana para pemegang saham (pesero) ikut serta dalam mengambil satu saham atau lebih dan melakukan perbuatan-perbuatan hukum yang dibuat oleh nama bersama, dengan tidak bertanggung jawab sendiri untuk persetujuan-persetujuan perseroan (dengan tanggung semata-mata terbatas pada modal yang mereka setorkan). ${ }^{22}$ Pemisahan harta dari para pemegang saham memberikan konsekuensi tanggung jawab yang terbatas dari para pemegang saham. Tiap pemegang saham hanya menderita kegian sebesar jumlah yang ditanamkan dalam perseroan terbatas yang bersangkutan. ${ }^{23}$

Perseroan dalam melakukan kegiatan usahanya dengan modal dasar yang terbagi atas saham-saham, maka secara prinsip pengurus tidak dapat dipertanggungjawabkan atas harta pribadinya, jika perseroan yang masih ada, akan dibagi secara seimbang di antara semua kreditur. Proses inilah yang terjadi dan diatur dalam Undang-Undang No. 37 Tahun 2004 Tentang Kepailitan dan Penundaan Kewajiban Pembayaran Utang.

\section{A. Kepailitan Perseroan Terbatas}

Kepailitan sering dipahami tidak tepat oleh kalangan umum. Sebahagian orang menganggap kepailitan sebagai vonis yang merupakan tindakan kriminal serta merupakan suatu cacat hukum atas subjek hukum, karena itu kepailitan harus dijauhkan atau dihindari sejauh mungkin. ${ }^{24}$ Lebih lanjut dijabarkan bahwa kepailitan secara apriori dianggap sebagai kegagalan yang disebabkan karena kesalahan debitur dalam menjalankan usahanya sehingga menyebabkan utang tidak mampu dibayar sehingga kepailitan sering diidentikkan dengan penemplangan utang atau penggelapan terhadap hak-hak yang seharusnya dibayarkan kepada kreditor.

Menurut Munir Fuady ${ }^{25}$ pailit atau bangkrut adalah suatu sitaan umum atas seluruh harta debitur agar dicapai perdamaian antara debitur dan para kreditur agar harta tersebut dapat dibagi-bagi secara adil di antara para kreditur. Kepaiitan

22 C.S.T.Kansil 2001. Hukum Perusahaan Indonesia (Aspek Hukum Dalam Ekonomi) Bagian I. PT Pradnya Paramita:Jakarta, hlm. 91 hlm. 82

${ }^{23}$ M.Manullang, 2002, Pengantar Bisnis. Gadjah Mada University Press:Yogyakarta,

${ }^{24}$ Hadi Subhan, 2008, Hukum Kepailitan, Prinsip, Norma, dan Praktik di Peradilan, Kencana: Jakarta, hlm. 2

${ }^{25}$ Munir Fuady 2002, Hukum Pailit 1998 (Dalam Teori dan Praktek) PT Citra Aditya Bakti:Bandung.hlm. 8 
berarti segala hal yang berhubungan dengan pailit dalam hal ini sangat berhubungan dengan ketidakmampuan untuk membayar dari seorang debitur atas utang-utangnya yang jatuh tempo. ${ }^{26}$ Dalam Black's Law Dictionary, Henry Campbell Black menyatakan, bankrupt is the state or condition of one who is unable to pay his debts as they are, or be become due.

Pada dasarnya pailit merupakan suatu keadaan dimana debitur tidak mampu untuk melakukan pembayaran-pembayaran terhadap utang-utang karena kesulitan kondisi keuangan (financial distress). Ketidak mampuan tersebut harus disertai dengan suatu tindakan nyata untuk mengajukan baik yang dilakukan secara sukarela oleh debitor sendiri maupun permintaan pihak ketiga. Kepailitan merupakan sita umum atas seluruh harta debitor pailit, baik yang telah ada maupun yang akan ada dikemudian hari.

Syarat utama untuk dapat dinyatakan pailit bahwa seorang debitor mempunyai paling sedikit 2 (dua) kreditor dan tidak membayar lunas salah satu utangnya yang sudah jatuh waktu ${ }^{27}$. Pernyataan pailit ini dapat dimohonkan oleh salah seorang atau lebih kreditor ${ }^{28}$, debitor atau pun jaksa penuntut umum untuk kepentingan umum. Dalam pengaturan kepailitan berangkat dari kepentingan kreditor dan debitor sendiri maupun kreditor lainnya. Dalam penjelasan UU Kepailitan dijabarkan ada bebarapa faktor yang menjadi dasar pengaturan mengenai kepailitan dan Penundaan Kewajiban Pembayaran Utang:

a) Menghindari perebutan harta debitor apabila dalam waktu yang sama ada beberapa debitor yang menagih piutangnya dari debitor;

b) Menghindari adanya kreditor pemegang hak jaminan kebendaan yang menuntut haknya dengan cara menjual barang debitor tanpa memperhatikan kepentingan debitor dan para kreditor lainnya;

c) Menghindari adanya kecurangan-kecurangan yang dilakukan oleh salah seorang kreditor atau debitor sendiri.

Dasar kepailitan sebenarnya bertitik tolak dari Pasal 1131 KUHPerdata, yang menentukan bahwa:

segala kebendaan si berutang, baik bergerak, maupun tak bergerak, baik yang sudah ada maupun yang baru akan ada di kemudian hari, menjadi jaminan bagi perikatan tersebut.

\footnotetext{
${ }^{26}$ Gunawan Wijaya, 2002, Op.cit., hlm.11

${ }^{27}$ Lihat penjelasan UUK Pasal 2 ayat (1)

${ }^{28}$ Kreditor yang dimaksud adalah kreditor konkuren, kreditor separatis, maupun kreditor
} preferen. 
Konsekuensi pasal tersebut, maka sekalipun tidak diperjanjikan dengan tegas, perseroan (debitor) bertanggung jawab terhadap segala harta dan barangbarang yang dimilikinya, baik bergerak maupun tidak bergerak, baik yang sudah ada maupun yang akan ada dikemudian hari.

Pertanggungjawaban dari perseroan (debitor) yang diatur dalam pasal 1131 KUHPerdata tersebut diselesaikan dengan lembaga kepailitan, sebab lembaga inilah mempunyai kompetensi untuk memeriksa perkara-perkara tersebut.

\section{B. Akibat Hukum Pernyataan Pailit suatu Perseroan Terbatas}

Akibat hukum yang ditimbulkan oleh kepailitan, sekalipun tidak sama sekali menghilangkan kecakapan untuk bertindak, mendekati akibat hukum terhadap sesorang yang ditempatkan dibawah pengampuan. Jika perseroan yang dinyatakan pailit, maka perseroan tidak biasa melakukan tindakan pengurusan dan pemilikan yang membawa akibat hukum yang merugikan harta kekayaan perseroan.

Pernyataan pailit mengakibatkan harta kekayaan debitor sejak putusan itu dikeluarkan dimasukkan ke dalam harta pailit. Menurut pasal 21 UUK, Seluruh harta kekayaan yang ada pada saat pernyataan pailit diputuskan, maupun terhadap semua kekayaan yang diperoleh debitor selama debitor berada dalam kepailitan.

Dengan adanya pernyataan pailit, debitor demi hukum kehilangan hak untuk menguasai dan mengurus harta kekayaannya yang dimasukkan ke dalam harta pailit terhitung sejak hari putusan pernyataan pailit tersebut. Apabila setelah putusan pernyataan pailit debitor masih juga tetap melakukan perbuatan hukum yang menyangkut harta kekayaannya, maka perbuatan hukum itu tidak mengikat kecuali apabila perikatan-perikatan yang dibuat itu mendatangkan keuntungan bagi harta pailit.

Dengan dinyatakannya pailit, maka debitor tidak memiliki kewenangan melakukan tindakan pengurusan dan pemilikan terhadap harta kekayaannya (asetnya). Namun demikian, tidak menghilangkan sama sekali kewenangan debitor untuk melakukan pengurus selama mendatangkan keuntungan bagi harta pailit tersebut. ${ }^{29}$

Menurut Fred B.G. Tumbuan dalam Hadi $\operatorname{Subhan}^{30}$ bahwa pernyataan pailit tidak dengan sendirinya mengakibatkan perseroan bubar. Oleh karenanya

${ }^{29}$ Sutan Remy Sjahdeini, 2002, Hukum Kepailitan. PT Pustaka Utama Grafiti:Jakarta. hlm. 258

${ }^{30}$ Hadi Subhan, 2008,, Op.cit., 205-206

Jurisprudentie | Volume 4 Nomor 2 Desember 2017 
perseroan pailit tetap cakap dan berwenang melakukan perbuatan hukum. Perseroan tetap dapat melanjutkan kegiatan usahanya kecuali dibubarkan. Pertimbangan utama melanjutkan kegiatan usaha perseroan terbatas yang dinyatakan pailit adalah nilai ekonomis (economic value) perusahaan yang jauh lebih tinggi dibanding nilai aset perusahaan tesebut. Oleh karena kepailitan sebenarnya diperuntukkan terhadap perusahaan yang mempunyai aset negatif. Namun demikian, keputusan untuk melanjutkan perseroan pailit mengakibatkan kekuasaan direksi dalam suatu perseroan terbatas dan badan-badan hukum lainnya yang mengelola perusahaan debitor atau badan hukum tersebut "terpasung", sekalipun mereka tetap menjabat dalam jabatannya tersebut. Pengurus perusahaan debitor atau badan hukum lainnya itu menjadi functus officio. Segala sesuatunya diputus dan dilaksanakan kurator. Debitor tidak memiliki kendali terhadap kurator, sebaliknya mereka harus mematuhi petunjuk-petunjuk dan perintahperintah kurator.

Berdasarkan hal tersebut di atas, maka gugatan-gugatan hukum yang menyangkut hak dan kewajiban berkenaan dengan harta kekayaan debitor pailit (perseroan) harus diajukan terhadap atau oleh kurator. Dengan kata lain, apabila ada pihak tertentu merasa mempunyai hak hak yang dapat diajukan kepada debitor (perseroan) pailit yang menyangkut harta perseroan tersebut, maka gugatan diajukan kepada kurator. Demikian pula sebaliknya, apabila perseroan pailit memiliki hak kepada pihak lain berkenaan dengan harta kekayaannya, maka gugatan terdahap pihak lain tersebut tidak lagi diajukan oleh perseroan akan tetapi diajukan oleh kurator.

Konsekuensinya, apabila ada pihak lain mengajukan gugatan kepada perseroan dan kemudian gugatan itu mengakibatkan penghukuman terhadap perseroan, maka penghukuman itu tidak mempunyai kekuatan terhadap harta pailit sebagaimana diatur dalam pasal 26 ayat (2) UUK. Sehubungan dengan ketentuan tersebut, timbul permasalahan mengenai kewenangan direksi untuk menggugat kurator dalam hal kurator melakukan perbuatan-perbuatan yang merugikan perseroan.

Dalam kondisi yang demikian maka direksi mewakili badan hukum, berhak untuk mengajukan gugatan karena pengajuan gugatan itu adalah untuk kepentingan harta pailit, bukan untuk mengurangi harta pailit. Perseroan juga berhak mengadukan perbuatan pidana yang dilakukan oleh kurator kepada pihak kepolisian atau kejaksaan. Relevan dengan pendapat hakim Peter Gibson J. dalam perkara Watts vs Midland bank, bahwa direksi diperkenankan melakukan derivative action terhadap receiver. Namun dalam perkara lain, yaitu perkara 
Gomb Holdings Ltd vs Homan, ternyata Hakim Hoffmann J. menolak untuk menerima kemungkinan demikian itu. ${ }^{31}$

Selama berlangsungnya kepailitan, maka segala tuntutan atau gugatan untuk memperoleh pemenuhan perikatan dari harta pailit, termasuk yang diajukan oleh perseroan, hanya dapat diajukan oleh penggugat sebagai laporan untuk verifikasi laporannya. Dengan kata lain, gugatan sebagaimna dimaksud dalam pasal 25 UUK tidak dapat ditertima oleh hakim sebagai gugatan dan diperiksa perkaranya tetapi hanya diterima sebagai laporan untuk pencocokan tagihannya dalam rangka verifikasi utang piutang dari perseroan tersebut. Hal ini sejalan dengan ketentuan pasal 24 ayat (1) yang menentukan bahwa gugatan yang bersumber pada kewajiban atas beban harta debitor pailit, tidak dapat diajukan oleh debitor sendiri tetapi kepada kurator.

Terhadap tuntutan yang menyangkut harta pailit, dalam hal debitor sebagai Tergugat berlaku ketentuan: ${ }^{32}$

1. Tergugat dapat minta penundaan untuk memanggil kurator

2. Bila kurator tidak mengindahkan panggilan, Tergugat berhak minta perkara digugurkan

3. Bila tidak, perkara dapat diteruskan dengan biaya di luar tanggungan harta pailit

4. Kurator dapat setiap waktu meminta debitur pailit dikeluarkan dari perkara; Kurator berwenang mengambil alih suatu perkara yang dihadapi oleh debitor pailit dan membebaskan debitor pailit yang bersangkutan dari persengketaan tersebut

Sedangkan tuntutan yang menyangkut harta pailit terhadap debitur sebagai Penggugat, maka berlaku ketentuan:

1. Penggugat berhak meminta penangguhan untuk menarik kurator

2. Bila kurator mengakui gugatan, biaya perkara pihak lawan bukan utang harta pailit

3. Bila kurator tidak menghadap, maka ketentuan Pasal 24 ayat (2) tidak berlaku

Untuk memperoleh pemenuhan perikatan dari harta pailit, sepanjang gugatan terhadap debitor (perseroan) yang sedang berjalan yang diajukan oleh penggugat dengan tujuan agar dipenuhi hal-hal yang ditentukan dalam perikatan yang menyangkut harta pailit, maka perkaranya harus ditangguhkan lebih dahulu untuk selanjutnya mengikuti proses verifikasi.

\footnotetext{
${ }^{31}$ Sutan Remy Sjahdeini, 2002, Op.Cit., hlm. 259.

${ }^{32}$ Locit, , hlm. 260
} 
Kegiatan verifikasi merupakan kegiatan pencocokan dan atau pemberesan terhadap semua utang debitor yang dinyatakan pailit yang dilakukan dalam rapat verifikasi. Jika ternyata piutang penggugat dibantah, maka pihak yang membantah piutang tersebut maju menggantikan kedudukan debitor (perseroan) sebagai tergugat dalam perkara yang ditangguhkan itu. Dalam hal suatu perkara dilanjutkan, yaitu perkara yang diajukan oleh atau terhadap kurator atau perkara sebagaimana dimaksud dalam pasal 30 UUK, maka kurator maupun kreditur yang bersangkutan dapat mengajukan pembatalan atas segala perbuatan debitor (perseroan) yang dilakukan sebelum dinyatakan pailit, apabila bahwa perbuatan perseroan tersebut merugikan para krediturnya dan hal yang demikian itu diketahui pihak lawan. Ketentuan tersebut sebagaimana diatur dalam pasal 30 UUK dan dihubungkan dengan pasal 42 UUK yang mengatur mengenai action pauliana.

Ketentuan mengenai sita dan eksekusi atas harta perseroan akibat kepailitan, baik sebahagian maupun seluruhnya, yang telah diputuskan sebelum pernyataan pailit tersebut wajib segera dihentikan. Dalam hal terdapat perjanjian timbal balik berkenaan dengan harta kekayaan perseroan yang dinyatakan pailit, maka pihak yang mengadakan perjanjian tersebut dapat meminta kepada kurator untuk memberikan kepastian tentang kelanjutan pelaksanaan perjanjian tersebut. Hal ini berbeda dengan kreditor yang memegang hak tanggungan yang dapat mengeksekusinya haknya seolah-olah tidak terjadi kepailitan dalam jangka waktu paling lama 90 (sembilan puluh hari) hari terhitung sejak tanggal pailit ditetapkan.

\section{PENUTUP}

Dapat disimpulkan bahwa kepailitan mengakibatkan debitor tidak memiliki kewenangan melakukan tindakan pengurusan dan pemilikan terhadap harta kekayaannya kecuali apabila perbuatan hukum tersebut mendatangkan keuntungan bagi harta pailit. Gugatan-gugatan hukum yang menyangkut hak dan kewajiban berkenaan dengan harta kekayaan debitor pailit (perseroan terbatas) harus diajukan terhadap atau oleh kurator. Namun putusan kepailitan tidak menbebaskan perseroan terbatas yang dinyatakan pailit dari kewajiban-kewajiban membayar utangnya. 


\section{DAFTAR PUSTAKA}

Ahmad Yani dan Gunawan. 1999. Kepailitan. PT RajaGrafindo Persada. Jakarta.

Chatamarrasjid. 2000. Menyingkap Tabir Perseroan (Piercing The Corporateveil) Kapita Selekta Hukum Perusahaan. PT Citra Aditya Bakti:Bandung.

C.S.T. Kansil. 2001. Hukum Perusahaan Indonesia (Aspek Hukum Dalam Ekonomi) Bagian I. PT Pradnya Paramita:Jakarta

Black, Henry Campbell, Black's Law Dictionary. ST.Paul Minn West Publising Co, USA, 1990.

Garner, A. Bryan, Black's Law Dictionary, $9^{\text {th }}$ edition, St Paul, West, 2009.

Hadi Subhan, Hukum Kepailitan, Prinsip, Norma, dan Praktik di Peradilan, Kencana: Jakarta, 2008

Kelly, David, et.al., Business Law, Cavendish Publishing Limited, London, 2002.

Leo Faraytody. Jangan Tunggu Langit Runtuh. Hukumonline.com. 2003

Lewis, Athur, alih bahasa Derta Sri Widowatie, Introductioan to Bisnis Law (Dasar-dasar Hukum Bisnis), Nusa Media, Bandung, 2009.

M.Manullang. Pengantar Bisnis. Gadjah Mada University Press:Yogyakarta, 2002

Munir Fuady.Hukum Pailit 1998 (Dalam Teori dan Praktek) PT Citra Aditya Bakti:Bandung.2002

Perseroan Terbatas dalam Paradigma Hukum Bisnis Baru ,PT Citra Aditya Bakti Bandung, 2002.

Peter Mahmud Marzuki, Pengantar Ilmu Hukum, Kencana Prenada Media Group, Jakarta, 2008.

Purnadi Purbacaraka dan Agus Brotosusilo, Sendi-sendi Hukum Perdata, CV Rajawali, Jakarta, 1983.

Ridwan Khairandy, Perseroan Terbatas, Doktrin, Peraturan Perundangundangan dan Yurisprudensi, Kreasi Total Media, Yogyakarta, 2009.

Rochmat Soemitro, Penuntun Perseroan Terbatas dengan Undang-undang Pajak Perseroan, PT Eresco Bandung, Jakarta, 1979.

Rudhi Prasetya, Kedudukan Mandiri Perseroan Terbatas, Citra Aditya Bakti, Bandung, 2001.

Sutan Remy Sjahdeini. Hukum Kepailitan. PT Pustaka Utama Grafiti:Jakarta, 2002

Undang-Undang No. 40 Tahun 2007 Tentang Perseroan Terbatas

Undang-Undang No. 37 Tahun 2004 Tentang Kepailitan dan Penundaaan Kewajiban Pembayaran Utang 